\title{
Water Quality in the Floridan Aquifer Region ${ }^{1}$
}

\author{
Natalie A. Cooper and Martha C. Monroe ${ }^{2}$
}

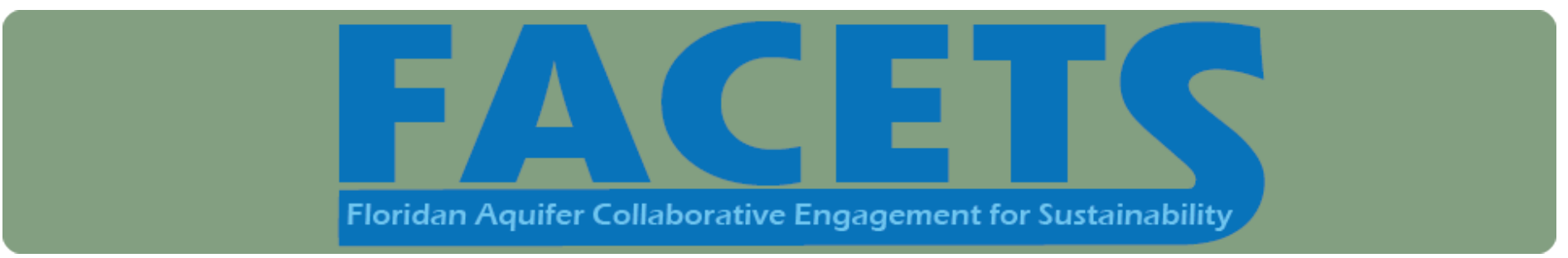

\section{Our Relationship with Water}

We rely on clean, fresh water to sustain human life, ecosystems, and food supply. Our fresh water can come from surface water (e.g., rivers) or groundwater sources. In Florida and southwest Georgia, groundwater from the Floridan Aquifer supplies much of the freshwater we consume, including drinking water for approximately $90 \%$ of Florida's total population (USGS 2008). People also use water for a range of activities, from household needs like washing dishes to commercial enterprises like mining or agricultural irrigation to industrial processes like the production of the energy we use to power our homes and factories. All of these activities can introduce contaminants into the water. Contaminants are defined as any particulate or dissolved substance we introduce into our water through human activity. Once contaminant concentrations exceed levels deemed safe by society, the degraded water is considered polluted (Boulding and Ginn 2016). As populations grow and regional economies expand, the impacts of human activity on ground and surface water pollution become more widespread. Therefore, we must take preventative actions to minimize water pollution and maintain the quality of our water sources, and, thus, our quality of life.

\section{Water Pollution}

Both surface water and groundwater are susceptible to pollution. Water pollution can come from point or nonpoint sources. Point sources refer to pollutants that can be traced to specific locations (e.g., wastewater treatment plant outflow), and they are addressed through regulatory permitting and compliance (EPA 2020a). Non-point sources are discharges from less concentrated but more widespread sources (e.g., septic tanks, agricultural and urban water runoff, or contaminated water that washes across compact land surfaces into water bodies). These sources are more difficult to trace, regulate (Boulding and Ginn 2016), and control. Therefore, cumulative non-point pollution makes a bigger overall impact on water quality. The best way to reduce the impact of non-point water pollution is through prevention rather than clean up (Mylavarapu 2014).

1. This document is FOR371, one of a series of the School of Forest Fisheries and Geomatic Sciences. Original publication date October 2021. Visit the EDIS website at https://edis.ifas.ufledu for the currently supported version of this publication. This document is based upon work that is supported by the National Institute of Food and Agriculture, U.S. Department of Agriculture, under award number 2017-68007-26319. Any opinions, findings, conclusions, or recommendations expressed in this publication are those of the author(s) and do not necessarily reflect the view of the U.S.

Department of Agriculture.

2. Natalie A. Cooper, graduate research assistant and PhD candidate, School of Forest, Fisheries, and Geomatics Sciences;and Martha C. Monroe, professor and associate director, School of Forest, Fisheries, and Geomatics Sciences, UF/IFAS Extension, Gainesville, FL 32611.

The Institute of Food and Agricultural Sciences (IFAS) is an Equal Opportunity Institution authorized to provide research, educational information and other services

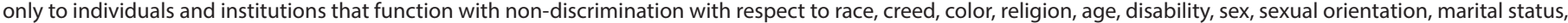

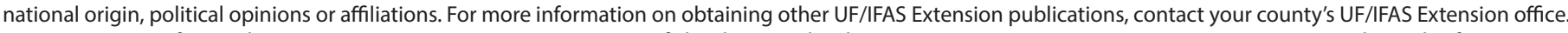
U.S. Department of Agriculture, UF/IFAS Extension Service, University of Florida, IFAS, Florida A \& M University Cooperative Extension Program, and Boards of County Commissioners Cooperating. Nick T. Place, dean for UF/IFAS Extension. 


\section{Unconfined Aquifers Make Groundwater More Vulnerable to Pollution}

A confined aquifer or region of an aquifer has a layer of impermeable material, often consisting of clay, nestled between the land surface and the aquifer. This layer helps prevent contaminants introduced above ground from seeping into the groundwater. Unconfined aquifers lack this protective underground barrier, so they are especially vulnerable to groundwater pollution. Therefore, preventative management practices are critical for water quality in these areas.

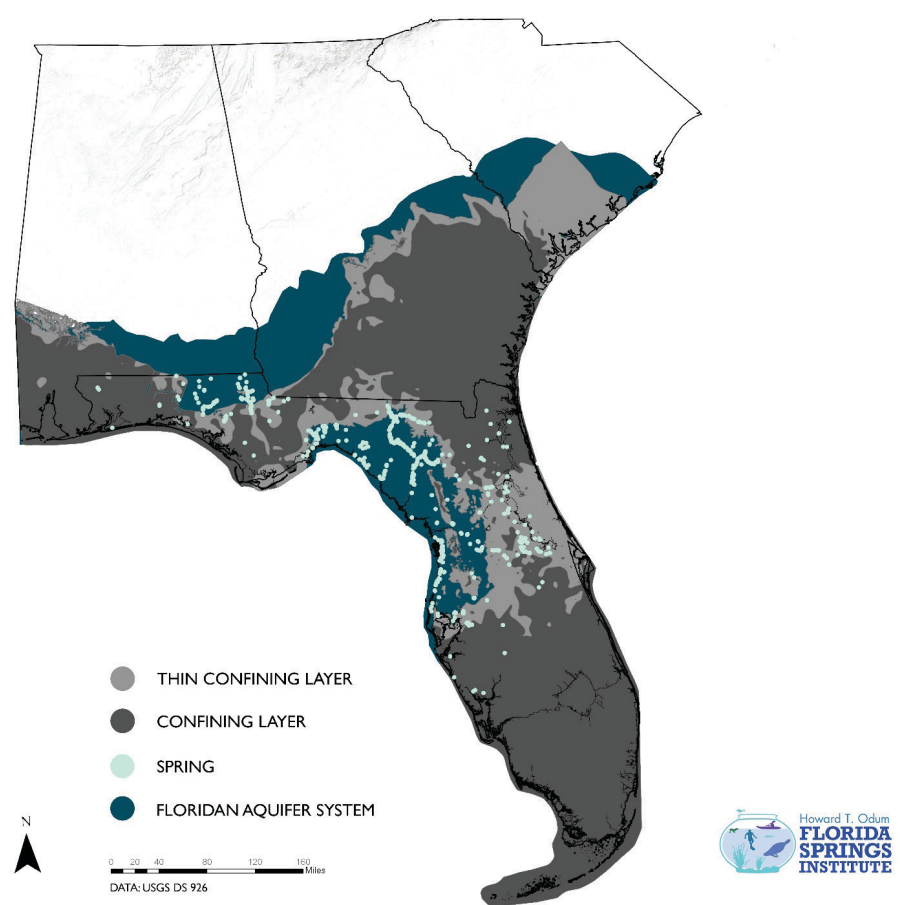

Figure 1. Floridan Aquifer Confinement Map.

Credits: Haley Moody, Howard T. Odum Florida Springs Institute

The largest extent of the Upper Floridan Aquifer's unconfined area underlies north Florida and southwest Georgia. Agriculture, forestry, and residential development are prevalent land uses in these regions. The population of the region continues to expand, which increases the amount of construction, septic systems, and fertilizer application, as well as the area of paved surfaces around urban landscapes. All of these land uses and activities can introduce contaminants into water resources. A combination of heavy rainfall, sandy soils that drain easily, and a porous limestone aquifer create conditions for rapid replenishment of the groundwater (Furman et al. 1975). On the one hand, the well-drained soils are advantageous for the region's water supply and water-dependent activities-groundwater in these areas recharges quickly. For example, farmers have a reliable water source for irrigation of agricultural crops. On the other hand, sandy soils do not hold water well, are less fertile, and permit many contaminants to remain in water as it seeps toward the aquifer. In the example of farmers, these conditions require them to add nutrients to the soil, and unfortunately some cannot be filtered through natural processes and thus contaminate the groundwater. The age of the water discharging from spring vents can vary from days or weeks to decades old (Cohen 2008); therefore, the amount of time it takes for water (and potential contaminents) to travel through the aquifer into the groundwater is highly variable.

\section{Nutrient Pollution}

Non-point-source nutrient pollution is currently the leading cause of water quality degradation throughout the region as well as across the United States (Berndt et al. 2014). Nutrients are chemical elements (natural or manufactured) critical to growth in plants and animals. To varying degrees, growers apply nutrient fertilizers as well as pesticides to manage their crops, pasture, or forests. They are also used commonly for lawns and commercial landscaping. Nitrogen and phosphorus are the primary nutrients applied in fertilizers and are necessary to support agricultural production, especially in lands with nutrientpoor soils. These are also key non-point contaminants affecting surface water pollution (Mylavarapu 2014), and nitrogen (in the form of nitrate) is the most widespread non-point contaminant affecting groundwater pollution (FDEP 2020). If more nutrients are applied than can be taken up by plants, then rain or heavy irrigation can transport them along with pesticides and other substances over land to nearby lakes, streams, and wetlands, or downward to infiltrate the groundwater. Urban areas have many impermeable surfaces like rooftops and paved streets and parking lots, with fewer permeable areas like green spaces that soak up rainfall. These conditions further promote water runoff. Urban runoff often contains oils and heavy metals from automobile fluids.

Septic systems are another important source of non-point nutrient pollution, as household waste discharged from sinks, baths, toilets, and appliances contains significant amounts of nitrogen and phosphorus. Many septic systems are located along coastal areas where the water table is shallow and where sandy soils permit rapid transport of contaminants to groundwater, especially during the rainy season (Toor et al. 2011). A typical septic system (tank and drain field) only removes about $30 \%-40 \%$ of nitrogen in wastewater, so the remaining $60 \%-70 \%$ can reach the groundwater and even pollute local drinking water if too close to a well (Toor et al. 2011). Poorly maintained septic 
systems can lead to wastewater flooding above ground, and the untreated wastewater may contaminate nearby streams, lakes, or coastal waters (EPA 2020b).

Other common sources of water nutrient pollution include animal feed lots, land application of manure, industrial and municipal wastewater, sanitary landfills, and older garbage dumps (MCPA 2008).

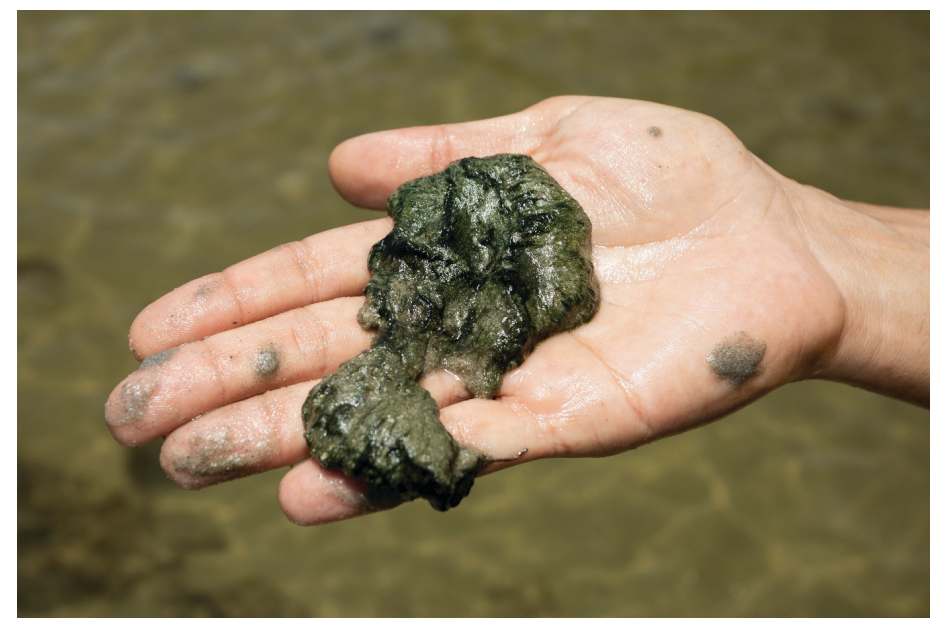

Figure 2. Algae in the palm of a hand. Photo taken 07-10-2019. Credits: Tyler Jones, UF/IFAS

Certain events or actions can exacerbate water quality degradation. For example, significant rainfall with major storms or hurricanes can flood drainage systems, overload wastewater collection systems and treatment plants, and send a surge of pollutants into the water system. Also, over time, heavy groundwater withdrawal (i.e. for crop irrigation and municipal use) and replacement of withdrawn groundwater with contaminated water recharge results in an increasingly polluted groundwater supply.

\section{Effects of Nutrient Pollution}

\section{Eutrophication}

Excess nutrients in surface waterbodies can disrupt and degrade aquatic ecosystems because they cause water quality degradation called eutrophication. Eutrophication occurs when an overabundance of nutrients stimulates algal growth, which reduces the ability of sunlight to penetrate to rooted aquatic plants. As aquatic plants die off, the food and habitat they provided for aquatic animals diminishes (Mylavarapu 2014). Microorganisms that decompose the dead plants and algae use up dissolved oxygen, which can stress or kill fish and other aquatic organisms. Certain species of algae also produce chemical toxins during blooms, which can harm both animals and humans. Some results of excessive eutrophication are visible: thick mats of algae in the water, scum and foam, odor and taste problems, and wildlife death. These changes can make way for invasive aquatic plants, which can take over like pests and interfere with boating, fishing, and swimming (Dukes et al. 2020). In surface waters like lakes and rivers, eutrophication is often a consequence of contaminated water runoff.

\section{Groundwater Pollution: Risks to Human Health and Eutrophication of Freshwater Springs}

In areas where the Floridan aquifer is unconfined and overlain by sandy soils, excess nitrate from agricultural lands or septic systems is easily transported into the Floridan Aquifer groundwater supply. More severe cases of nitrate contamination in groundwater can harm human health, which is why the EPA established the Maximum Contaminant Level (MCL) at 10 milligrams of nitrate-nitrogen per liter ( $\mathrm{mg} / \mathrm{l})$ of water. Ingestion of nitrate-contaminated water and foods is associated with an array of illnesses, including blue baby syndrome (methemoglobinemia) among infants, who are most vulnerable to the potential health impacts of nitrate contamination (WQA 2013). Elevated nitrate levels are of less concern for public drinking water supply, which is drawn from deep in the aquifer and regulated according to the MCL standard (10 $\mathrm{mg} / \mathrm{l}$ ); however, they do pose risk for households reliant on unregulated private domestic wells that draw from shallow groundwater (surficial aquifers) in or near agricultural communities or near septic systems. In addition to potentially harming human health, groundwater contamination can depreciate property values up to $15 \%$ where domestic wells supply water (Guignet and Northcutt 2016).

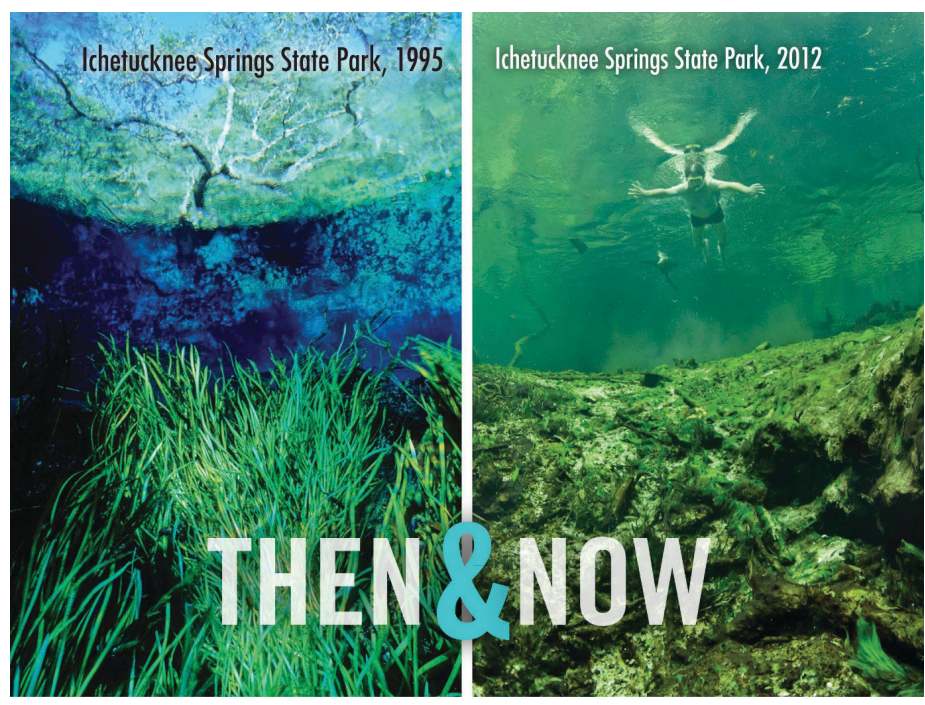

Figure 3. Then and Now. Algae takeover at Ichetucknee Springs State Park, FL, 1997 and 2012. Photos in identical locations.

Credits: John Moran 
Throughout north central Florida and southwestern Georgia, groundwater discharges into freshwater springs. Over recent decades, increases in groundwater nitrate concentrations have been associated with eutrophication and degraded springs ecology in both states: many spring runs have experienced more nuisance aquatic vegetation, reduced clarity, and harmful algal blooms (Berndt et al. 2014). Springs degradation can negatively impact water recreation and related enterprises in local and regional economies. Signs of degraded spring water quality serve as warnings for regional groundwater quality.

\section{Additional regulatory measures: Are they working?}

Prior to 2013, Georgia and Florida both adhered to the same groundwater quality standards set to protect human health. However, in 2013, Florida created an additional standard aimed at better protecting its abundant freshwater springs ecosystems, which are sensitive to nitrate contamination and central to regional tourism. The ecosystemprotective numeric nutrient criteria standard of $0.35 \mathrm{mg} / \mathrm{l}$ is applied to groundwater that emanates from the springs (FDEP 2013), which of course emerges from the aquifer.

A 2020 Florida water quality assessment indicated that more than $75 \%$ of frequently monitored springs had nitrate-nitrogen concentrations above the $(0.35 \mathrm{mg} / \mathrm{l})$ threshold (FDEP 2020). Groundwater samples were also taken from wells, and most cases of nitrate exceedences occurred in rural agricultural areas, including three cases that surpassed that human health safety $(10 \mathrm{mg} / \mathrm{l})$ standard (FDEP 2020). Notably, it can take decades for changes in nitrogen inputs on land to appear in the nitrate concentrations in groundwater (Berndt et al. 2014).

\section{How to Prevent and Control Nutrients}

There are many preventative actions people can take to reduce the amount of nutrients that end up in our water bodies and groundwater. For example:

\section{Individuals can...}

- Reduce the use of lawn fertilizer.

- Keep grass clippings on the lawn so that the nutrients released by the decomposing plant material can be taken up by the growing grass. This reduces the need to add fertilizers.
- Maintain buffer strips (or natural barriers) of native, deep rooted vegetation on shorelines or along streams. Natural vegetation can filter some of the nutrients in runoff that would otherwise flow easily from fields or lawns into nearby waterways.

- Regularly maintain septic systems. Where possible, upgrade to more modern and effective septic systems.

\section{Rural producers can...}

- Implement agricultural and silvicultural Best Management Practices (BMPs), which are means and practices that combine good stewardship sense with cost-effective technology to help conserve water and improve water quality in ways that support agricultural productivity. Cost-share programs exist to financially support the adoption of these practices.

\section{Public and private water managers and planners can...}

- Where possible, use reclaimed water for irrigation (e.g., of turf, landscape plants) - in combination with the appropriate nutrient management-to conserve potable water and reduce fertilizer application. Reclaimed water (also referred to as "recycled" or "reuse" water) is the water that comes out of a wastewater treatment plant. This water has been disinfected and is safe for non-drinking purposes and often contains nutrients (nitrogen and phosphorus). Reclaimed water providers may be consulted about water nutrient levels to inform proper management of irrigated landscapes. By using reclaimed water instead of potable water to irrigate golf courses, lawns, and other vegetated areas, we can potentially reduce the need to apply commercial fertilizer, conserve potable water, and reduce landscaping costs all at once. (For more information, see http://blogs.ifas.ufl.edu/extension/2017/06/20/ reclaimed-water-frequently-asked-questions/)

- Where possible, municipalities can connect people who are currently on septic systems to the municipal wastewater treatment system. Central wastewater treatment plants are often more effective at removing nutrients. Upgrades to septic systems improve (but do not eliminate) the leakage of nutrients like nitrogen and other potentially harmful substances. Many households, especially in rural areas, may require financial assistance to maintain or replace septic systems.

- Preserve natural wetlands and create constructed wetlands as a natural, low-cost alternative to treat domestic wastewater, non-point source pollution, and stormwater runoff. Wetlands also benefit local communities with 
educational, floodwater storage, recreational, wildlife habitat and aesthetic value (Capasso et al. 2019).

\section{Other strategies...}

- Design, construct, and operate additional Regional Stormwater Treatment areas (RSTs), which are stormwater treatment sites in key locations of connected water bodies (e.g., rivers) that remove nutrients from drainage waters of priority agricultural basins before they get discharged to surface waters at the basin outlet (https:// floridadep.gov/sites/default/files/adopted-lsjr-bmap.pdf).

\section{References}

Ahmed et al. 2017. "Excessive Use of Nitrogenous Fertilizers: An Unawareness Causing Serious Threats to Environment and Human Health." Environmental Science and Pollution Research 24:26983-26987. https://doi.org/10.1007/ s11356-017-0589-7

Berndt, M. P., B. G. Katz, J. A. Kingsbury, and C. A. Crandall. 2014. "The Quality of Our Nation's Waters: Water Quality in the Upper Floridan Aquifer and Overlying Surficial Aquifers, Southeastern United States, 1993-2010." US Geological Survey Circular 1355. USGS, Reston, VA. https://pubs.usgs.gov/circ/1355/pdf/circ1355.pdf

Boulding, J. R., and J. S. Ginn. 2016. Practical Handbook of Soil, Vadose Zone, and Ground-Water Contamination: Assessment, Prevention, and Remediation. CRC Press.

Capasso, J., L. Krimsky, and J. Bhadha. 2019. Wetlands as a Tool for Water Treatment. EDIS 2019 (5)7. https://doi. org/10.32473/edis-fr419-2019

Cohen, M. 2008. Springshed Nutrient Loading, Transport and Transformations. Summary and Synthesis of the Effects of Nutrient Loading on Spring Ecosystems and Organisms. Florida Department of Environmental Protection, pp. 53-134.

Dukes, M.D., L. Krimsky, M. Lusk, L. Trenholm, B. Unruh, M. Atkinson, and R. Mylavarapu. 2020. "Urban Fertilizer Ordinances in the Context of Environmental Horticulture and Water Quality Extension Programs: Frequently Asked Questions." EDIS 2020 (1). https://doi.org/10.32473/ edis-ae534-2020

EPA. 2020a. National Pollutant Discharge Elimination System (NPDES). Environmental Protection Agency. Retrieved October 26, 2020, from https://www.epa.gov/npdes
EPA. 2020b. Septic Systems and Surface Water. Environmental Protection Agency. Retrieved August 10, 2020, from https://www.epa.gov/septic/ septic-systems-and-surface-water

FDEP. 2010. Florida Springs Initiative Monitoring Network Report and Recognized Sources of Nitrate. Florida Department of Environmental Protection, Division of Environmental Assessment and Restoration, Bureau of Watershed Restoration, Ground Water Protection Section, Tallahassee, FL.

FDEP. 2020. Integrated Water Quality Assessment for Florida. Florida Department of Environmental Protection, Talahassee, FL. https://floridadep.gov/sites/default/ files/2020_IR_Master_FINAL\%20-\%20ADA.pdf

Furman, A.L., H.O. White, O.E. Cruz, W.E. Russell, and B.P. Thomas. 1975. Soil Survey of Lake County Area, Florida. Natural Resources Conservation Service, USDA, Washington, DC. Available at www.nrcs.usda.gov/Internet/ FSE_MANUSCRIPTS/florida/lakeareaFL1975/Lake.pdf.

Guignet, D., P. J. Walsh, and R. Northcutt. 2016. "Impacts of Ground Water Contamination on Property Values: Agricultural Run-Off and Private Wells." Agricultural and Resource Economics Review 45 (2): 293-318.

Marella, R. F. 2008. Water Use in Florida, 2005 and Trends 1950-2005. US Geological Survey Fact Sheet 3080. 6 pp. https://pubs.usgs.gov/fs/2008/3080/

Minnesota Pollution Control Agency - MPCA. 2008. Nutrients: Phosphorus, Nitrogen Sources, Impact on Water Quality - A General Overview. Water Quality/Impaired Waters \#3.22. Available at https://www.pca.state.mn.us/ sites/default/files/wq-iw3-22.pdf

Mylavarapu, R. 2014. "Impact of Phosphorus on Water Quality." SL 275. Gainesville: University of Florida Institute of Food and Agricultural Sciences. https://edis.ifas.ufl.edu/ ss 490

Toor, G. S., M. Lusk, and T. Obreza. 2011. “Onsite Sewage Treatment and Disposal Systems: Nitrogen.” SL 348. Gainesville: University of Florida Institute of Food and Agricultural Sciences. https://edis.ifas.ufl.edu/ss550

WQA. 2013. Nitrate/Nitrate Fact Sheet. WQA Technical Fact Sheet. Water Quality Association, Lisle, IL. Accessed October 26, 2020, from https://www.wqa.org/Portals/0/ Technical/Technical\%20Fact\%20Sheets/2014_NitrateNitrite.pdf 